что все самоактуализирующейся люди обладают способностями к творчеству, причём творческий потенциал присутствует в повседневной жизни как естественный способ выражения наблюдательной, воспринимающей новое личности. Согласно А. Маслоу, первоначальным источником творчества является потребность в самоактуализации, полной и свободной реализации своих способностей жизненных возможностей. По мнению К. Роджерса, творческие способности человека направлены на возможность достижения “идеального Я”. Таким образом, согласно гуманистическому направлению, творческим способности - это основание для непрерывного развития и самоактуализации, человека, они являются частью его природы.

Подводя общий итог, можно сказать, что в зарубежной психологии творческие способности часто отождествляются с креативностью определяются как стремление человека создавать нечто новое, оригинальное. Создаваемый продукт, а так же сам процесс творческой деятельности будет являться базой для самоактуализации и роста “идеального Я". При анализе всех подходов можно сделать выводы что все они основываются на природе врожденных творческих способностей. Однако есть много разногласии в вопросе, где границы между природно-врождёнными способностями и приобретёнными во время мыслительной творческой деятельности. Психоанализ природу творческих способностей рассматривает на уровне бессознательного. Подходы гештальпсихологии, бихевиоризма и когнитивной психологии объединяет тот факт, что они все сводят изучение творческих способностей к высшей форме мышления, иными словами, превосходящей обычное логическое и рациональное мышление.

$$
* * *
$$

1. Рубинштейн С.Л. Основы общей психологии. - СПб., 1999. - С.540-543

\title{
Malikova K. \\ Problems of special education using information communication technology
}

Institute of retraining and advanced training of managers and specialists of the education system named after Abdulla Avloni

(Uzbekistan, Tashkent)

doi 10.18411/sciencepublic-04-05-2020-13

idsp sciencepublic-04-05-2020-13

\section{Abstract}

In today's era of globalisation, the whole industry can not be without information technology.in this article, opinions on the possibilities of using information technology in special education are explained.

Keywords: teaching, methodology, special education, Information Technology, Education, Training, computer.

\section{Аннотация}

В эпоху сегодняшней глобализации невозможно без информационных технологий охватить всю сферу.в данной статье изложены мнения о возможностях использования информационных технологий в специальном образовании.

Ключевые слова: обучение, методика, специальное образование, информационные технологии, образование, обучение, компьютер.

At present, it is understood that bringing the lives of people with special needs, in need of help closer to the norm, the problem of their social adaptation is incredibly urgent. Being a less protected category of the population, individuals with special needs in most cases are deprived of the opportunity not only to actively participate in the socio-economic, cultural and political life of society, but also to meet their communicative, cognitive and physical needs. 
The absence of the necessary conditions for full participation in the educational process, which is responsible for satisfying the individual needs and opportunities of the students, as well as the limited range of functional opportunities caused by the use of discriminatory methods of teaching, most of the young people are deprived of the opportunity to receive quality education, to have a good profession Precisely, barriers to education are one of the main reasons that hinder the full participation of individuals with special needs in the life of modern society.

At the same time, the use of the right to education, which is one of the fundamental rights of man, is associated with a number of problems that exist in society itself. One of the main needs for social adaptation of individuals with special needs is the system of attitude and change of views on these persons, improvement of the legislative system, reform of the educational system, as well as change of the main directions of social policy.

The hope for the solution of pressing issues of the reform of the educational system, including the special education system, today is largely due to the use of information and communication technologies in pedagogical practice, which, along with the possibility of optimizing the educational process and increasing the possibilities for the use of educational resources, create favorable conditions for mastering knowledge, activating creative abilities and.

In most cases, as soon as they are born in relation to individuals with special needs, they are deprived of the opportunity to participate, enjoy in the above-mentioned activities as a result of the occurrence of prejudices and discrimination in society.

Modern ICT (Information Communication Technology) provides unique opportunities for individuals with special needs to communicate, receive education and information, as well as conduct research activities. Therefore, it is possible to realize the most important goals of humanity through the use of information and communication technologies in other practical and social spheres of human activity.

A correctional education system that allows students to prepare and adapt to life in the conditions of a modern information society requires the creation of optimal conditions of the educational environment, which determines the individual needs of students and contributes to the minimization of the obstacles encountered in their education.

The creation of such conditions can be achieved through the implementation of comprehensive measures, as well as the provision of infrastructure of information technology, integration of ICT (Information Communication Technology.) into the curriculum and training of specialists in the application of ICT (Information Communication Technology) special education (1- picture).

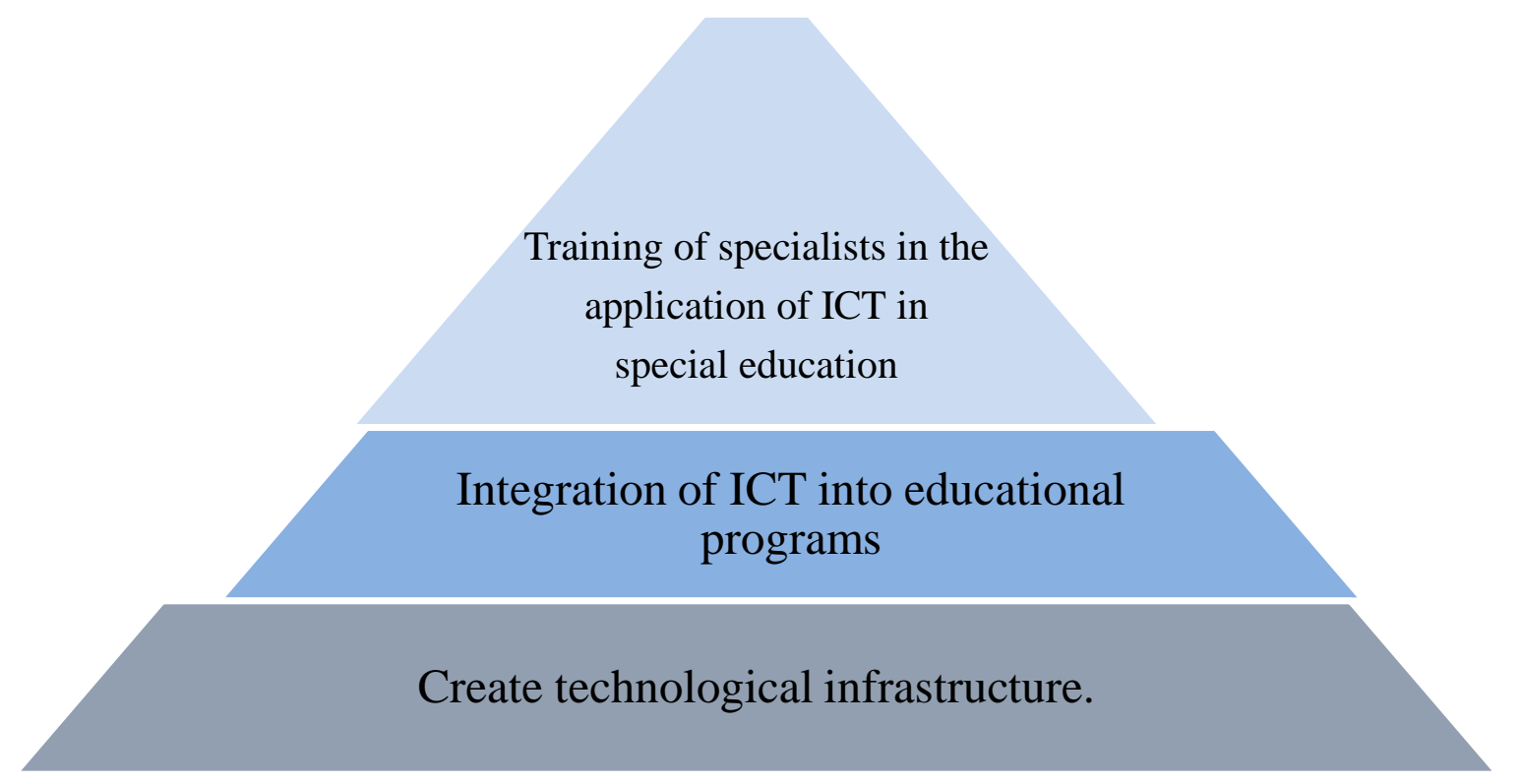

1-picture. To create optimal conditions of training through the use of Information Communication Technologies. 
The technologies used for teaching students with special needs can be divided into two categories: ancillary and corrective. Auxiliary technologies provide the possibility of physical access to information (for example, screen Loupe, speech input programs, specially developed mice and keyboards), and bunda correction technologies help to eliminate existing shortcomings and develop educational skills and skills.

When creating a curriculum of directed and integrated education, it is necessary to take into account the characteristics of development of students and their educational needs, as well as the application of appropriate teaching methods (taking into account these characteristics) based on the use of ICT Information Communication Technology) tools.

To effectively organize the correctional learning process, it is necessary to create a technological infrastructure that takes into account the needs of the user and the educational objectives.

The full integration of students with special needs into the educational process can not be carried out without the help of auxiliary technologies and special equipment. Bunda said that technological solutions can be the only method for some students when it comes to showing their needs, decisions and views to others. The elimination of a number of difficulties arising in the educational process in the integrated educational environment can be successfully carried out on the basis of the use of ICT (Information Communication Technology). The use of ICT (Information Communication Technology) significantly increases the possibilities of Correctional educational processes in the following areas:

- to diagnose the initial level of knowledge, skills and skills;

- help and correction in the development of the individual by forming new skills and abilities and enriching life experience;

— improve access to information;

- eliminate geographic or social blocking by creating conditions that facilitate interaction and communication.

At the same time, the creation of a suitable technological infrastructure can not solve all problems. In order to realize the next stage of the introduction of ICT (Information Communication Technology) into special education, it requires the creation and introduction of innovative teaching methods by teachers, as well as the willingness of existing approaches to change and adapt them in accordance with the new concept of special education and modern technologies.

If the reader does not have the opportunity to control or manage any activity, an alternative type of activity should be developed or adapted, which allows him to obtain the necessary information and then demonstrate the results. To accomplish this objective, it is necessary to ensure full integration of ICT (Information Communication Technology) into the curriculum. Bunda, the modification of the curriculum is not related to deviations from scientific requirements and standards. Changes in the curriculum should not be simplified for individual categories of students and should not reduce the demand for their knowledge and skills. On the contrary, the distribution of knowledge and educational resources requires the creative approach and ingenuity of the teacher.

Accessing data in real-time, combining the advantages of speed and convenience, has become the most common way to obtain information. In the study of Sciences, it is possible to use a variety of technologies that support the process of communication between students: synchronous and asynchronous communication tools and interactions (e-mail, forums, videoconferences, teleconferences, etc.), interactive elements (modeling and games in conditions close to reality), as well as various methods of control and evaluation (self-testing, testing of questions based on multiple choices, etc.).

The use of ICT (Information Communication Technology) education - allows to optimize the learning environment and provides an alternative and, most importantly, a format of educational resources that can be used by the user. Through the use of automated software development of training courses, the content of the training program can be presented in a 
variety of ways: as a text on the Internet site, as an animated image, virtual reality, as a multimedia product, including digital audio recording and video. In addition, the use of ICT (Information Communication Technology) allows teachers to interact professionally with their colleagues and at the same time to improve their skills and exchange experience.

$$
* * *
$$

1. АКТ в образовании людей $\mathrm{c}$ особыми потребностями: Специализированный учебный курс/Авторизованный пер.с англ./ Н.Токарева, С.Бесио - М.:Изд.дом «Обучение-Сервис», ISBN 5902116-20-1.

2. Commission of the European Communities (2000). Communication from the Commission to the Council, the European Parliament, the Economic and Social Committee and the Committee of the Regions: Towards a Barrier Free Europe for People with Disabilities. Brussels.

\section{Koshchukova A.A. \\ Analysis of the state of the problem of professional formation of novice teachers}

Belgorod State National Research University

(Russia, Belgorod)

doi 10.18411/sciencepublic-04-05-2020-14

idsp sciencepublic-04-05-2020-14

\section{Abstract}

The article discusses the professional formation of novice teachers, provides an analysis of the state of the problem of professional formation of novice teachers on the example of an educational organization.

Keywords: a novice teacher, a professional formation.

Currently there is an acute problem of transformation and replenishment of the education sector with «new» teaching staff. The actuality of attracting novice teachers is due to the «aging» of teaching staff, the rising of dynamism in the external environment, and, as you know, young people are easily and quickly trained, mobile, initiative, full of new ideas and mainly importantly they are - ready for innovations. According to such scientific researchers as Kazantseva L. A., Slastenin V. A., Andreev V. I., Dubinina V. L., a modern teacher is a new innovative type of teacher who initiates creative pedagogical innovations. The main characteristics of the activities of the "new" teacher include the readiness for change, the mobility, the ability to non-standard labor actions, the loyalty, as well as the independence of making decisions [2].

No less important is the problem of requesting parents who believe that only experienced, highly qualified teacher with experience should be their child's teacher. That's why, when the head of an educational institution decides to hire a novice teacher, then, first of all, his main task is to plan, organize, adjust and control their professional formation.

Professional formation takes one of the main places in the life of every person. This process involves the continuous development of personality has a different content, and different goals at different age stages. Professional formation is considered as the period during which the novice teacher forms professional skills, passes the adaptation period, reveals his intentions regarding the chosen profession, and the necessary personal qualities are developed [4].

An analysis of the literature shows that formation can be considered in three directions: as a personal development, as a transition from the old to the new in the formation's process, as an expression of the process of creating prerequisites to growth, to the new [3].

An important place in the professional formation of a novice teacher is occupied by the head of the educational organization, namely, how he organizes the management of this 